\title{
Poor socioeconomic state, stress, stunting and fatness are negatively associated with cognitive performance of female adolescents
}

\author{
${ }^{*}$ H J H Madhushanthi ${ }^{1}$, S W Wimalasekera ${ }^{2}$, C S E Goonewardena ${ }^{3}$, A A T D Amarasekara ${ }^{4}$, Janaka \\ Lenora $^{5}$
}

Sri Lanka Journal of Child Health, 2021; 50(4): 674-680

DOI: http://doi.org/10.4038/sljch.v50i4.9886

\begin{abstract}
Introduction: The brain undergoes dynamic structural and maturational changes during adolescence, producing significant changes in cognition and behaviour. Cognitive performance (CP) of an individual is influenced by many factors, nutritional, psychosocial and genetic.
\end{abstract}

Objectives: To determine the influence of nutritional and psychosocial factors on $\mathrm{CP}$ of early female adolescents in Sri Lanka.

Method: Two hundred and eighteen female adolescents, 11-14 years of age, were administered neurocognitive test batteries comprising tests of nonverbal intelligence, subtests of Wechsler Intelligence Scale for Children and two computer based executive function tests to assess CP. Height for age Z-score (HAZ), weight for age Z-score (WAZ) and BMI for age Z-score (BAZ) were calculated to measure nutritional status. Adolescent stress questionnaire (ASQ) was used to assess stress.

\begin{abstract}
${ }^{1}$ Senior Lecturer, Department of Nursing, Faculty of Allied Health Sciences, University of Ruhuna, Sri Lanka, ${ }^{2}$ Professor in Physiology, Department of Physiology, ${ }^{3}$ Professor in Community Medicine, Department of Community Medicine, Faculty of Medical Sciences, University of Sri Jayewardenepura, Sri Lanka, ${ }^{4}$ Senior Lecturer, Department of Nursing and Midwifery, Faculty of Allied Health Sciences, University of Sri Jayewardenepura, Sri Lanka, ${ }^{5}$ Professor in Physiology, Department of Physiology, Faculty of Medicine, University of Ruhuna, Sri Lanka *Correspondence: hemamali@ahs.ruh.ac.lk
\end{abstract}

\section{https://orcid.org/ 0000-0002-8732-9102}

(Received on 28 October 2020: Accepted after revision on 18 December 2020)

The authors declare that there are no conflicts of interest

Funding: The study was funded by the research grant from the University of Sri Jayewardenepura (ASP/06/RE/MED/2014/19).

Open Access Article published under the Creative

Commons Attribution CC-BY CC (i) License
Results: Fat mass percentage was inversely associated with working memory index (WMI) $(\mathrm{r}=-$ $0.34 ; \mathrm{p}<0.001)$ and processing speed index (PSI) $(\mathrm{r}=-0.39 ; \mathrm{p}<0.001)$. Multivariate regression analysis revealed that the combination of socioeconomic status (SES) index, HAZ and ASQ total score significantly predicts estimated full scale intelligence quota (EFSIQ). SES index was positively correlated with verbal comprehension index (VCI) $(\mathrm{r}=0.36 ; \mathrm{p}<0.01)$, working memory index (WMI) $(\mathrm{r}=0.30 ; \mathrm{p}<0.01)$, EFSIQ $(\mathrm{r}=0.31$; $\mathrm{p}<0.01)$, perceptual reasoning index (PRI) $(\mathrm{r}=0.27$; $\mathrm{p}<0.01)$, PSI $(\mathrm{r}=0.20 ; \mathrm{p}<0.01)$ and visuo-spatial working memory $(\mathrm{r}=0.17 ; \mathrm{p}<0.05)$.

Conclusions: Poor socioeconomic state, stress, stunting and fatness were negatively linked with cognitive performance of female adolescents.

(Key words: Socioeconomic state, Stunting, Fatness, Cognitive performance, Female adolescents)

\section{Introduction}

Ages 11 to 14 years, which is considered early adolescence, is characterized by significant physical, psychological, social and cognitive transformation ${ }^{1}$. The prefrontal cortex of the brain, involved in high order cognitive outcomes, undergoes a different development trajectory in adolescence $^{2}$. As cognitive performance (CP) is influenced by nutritional, environmental and genetic factors, any insult to nutrition and environmental factors during adolescence lead to alteration of cognitive tasks governed by the frontal $\operatorname{lobe}^{3}$. In early years of life, nutrition and socioemotional factors play a key role in cognitive development ${ }^{4}$. Earlier studies reported that school aged children with protein energy malnutrition had poor performance on cognitive tasks like attention, memory, executive function, visuo-spatial ability, learning and intelligence quotient ${ }^{5,6}$. A multiethnic cross sectional study conducted across four South East Asian countries demonstrated that poor nonverbal intelligence scores of school aged children were associated with underweight and stunting $^{7}$. Moreover, poor socio-economic status is associated with several cognitive deficits, language and executive function reading and school 
achievements $^{8,9}$. In Sri Lanka, data on effect of nutritional and psychosocial factors on $\mathrm{CP}$ of adolescents are meagre.

\section{Objectives}

To assess nutritional and psychosocial factors affecting CP of early female adolescent school children in the Galle educational zone.

\section{Method}

This descriptive cross-sectional study was conducted on randomly selected schools in the Galle educational zone in Sri Lanka. Two hundred and eighteen 11-14 year old female adolescents residing in the Galle city were recruited. Schools and classes were randomly selected representing all school categories classified by the Ministry of Education.

\section{Anthropometric measurements}

Weight, height, waist circumference (WC) and hip circumference (HC) were measured according to standard procedure. Body mass index (BMI), fat mass percentage (FM\%), waist hip ratio (WHR) and waist height ratio (WHtR) were calculated to assess nutritional status of participants. Height for age Z-score (HAZ), weight for age Z-score (WAZ) and BMI for age Z-score (BAZ) were calculated using WHO sex specific growth reference values for adolescents. Adolescents with HAZ, WAZ and BAZ reference value $<-2$ SD score were categorized as stunted, underweight and thinness respectively. Triceps and subscapular skinfold thickness were measured using a skinfold caliper according to standard protocol to determine body FM\%. FM\% was estimated using a validated fat percentage estimation equation developed for Sri Lankan children ${ }^{10}$. As WHtR does not vary with age and sex, a cutoff value could apply across all age groups, sexes and ethnic groups ${ }^{11}$

\section{Measurement of socio-economic and psychosocial adversities}

Socio-economic status (SES) is a composite index of parental education, occupation and income ${ }^{12}$. Parental occupational status was categorized using the 9 point Hollingshead occupation scale ${ }^{13}$, which closely matched modern occupations. Income to need ratio was calculated by dividing total family income by official poverty threshold (published by department of Census and Statistics, Sri Lanka) for a family of that size. Subsequently, income to need ratio, parental education and Hollingshead occupation scale rank were standardized and averaged to derive family SES composite score (SES index).

The interviewer-administered psychosocial adversity scale was used to assess psychosocially adverse factors. This scale has been widely used in previous child development studies conducted in Asia $^{14}$. Adolescence stress was assessed using the interviewer-administered adolescence stress questionnaire $(\mathrm{ASQ})^{15,16}$, comprising 51 items measuring 9 dimensions of adolescence stress including stress of home life, school performance, school attendance, romantic relationships, peer pressure, teacher interaction, future uncertainty, school/leisure conflict and emerging adult responsibility. It is a self-administered questionnaire, each item rated on a 5 point Likert scale where $1=$ not at all stressful/ irrelevant to me, $2=$ a little stressful, 3= moderately stressful, 4= quite stressful and $5=$ very stressful.

\section{Measurement of cognitive performance}

Three cognitive test batteries, Wechsler Intelligence tests, tests of non-verbal intelligence (TONI) and two computer based executive function tasks (inhibition and visuo-spatial working memory) were used for detailed assessment of CP. The individually administered fourth UK edition of Wechsler Intelligence Scale for Children (WISCIV), devised by Psychological Corporation, USA, measures various cognitive skills. It is widely used to assess cognitive function of children aged 6 years to 16 years 11 months. In this study, eight subtests of WISC were used to assess four cognitive domains: verbal comprehension index (VCI) (similarities, comprehension), working memory index (WMI) (digit span, symbol search), perceptual reasoning index (PRI) (picture completion, matrix reasoning) and processing speed index (PSI) (cancellation and arithmetic). The estimated full scale intelligence quota (EFSIQ) was calculated based on the sum of the eight subtest scores. WISC profile has been validated in Sri Lanka and used in previous national studies ${ }^{17}$. TONI-3 is free of language and culture bias and an objective method of examining cognitive function which does not require verbal or motor skills. It is widely used to measure abstract reasoning of individuals aged 6 to 90 years ${ }^{18}$. It has 45 items arranged in order of difficulty per test. Executive functions were assessed using two computer based tasks, pig house paradigm and stop signal paradigm, which assess visuo-spatial memory and inhibitory control respectively.

Ethical issues: Approval for the study was obtained from the Ethics Review Committee, Faculty of Medical Sciences, University of Sri Jayewardenepura, Nugegoda, Sri Lanka (Ref. No. 80/14 dated 26 February 2015) Before starting data collection, permission was obtained from the relevant school authorities while informed written consent was obtained from parents and assent from children. 
Statistical analysis: Statistical Package for Social Sciences version 20 was used to analyse data. Continuous variables not normally distributed were $\log$ transformed. Pearson correlation test was used to assess correlation of cognitive function tests scores with anthropometric and psychosocial variables. Variables with significance value $<0.25$ in bivariate analysis were included for regression analysis. Multivariate regression analyses were performed to predict the best combination of dependent variables on $\mathrm{CP}$. In the final regression model, $\mathrm{p}<0.05$ was considered significant.

\section{Results}

Table 1 presents the socio-demographic characteristics of study participants. Age of study participants ranged from 11 to 14 years with a mean of $12.31 \pm 1.16$ years.

\section{Table 1}

Socio-demographic characteristics of participants

\begin{tabular}{|c|c|}
\hline Variable & Frequency (\%) \\
\hline $\begin{array}{l}\text { Ethnicity } \\
\text { Sinhala } \\
\text { Muslim }\end{array}$ & $\begin{array}{c}185(84.9) \\
33(15.1)\end{array}$ \\
\hline $\begin{array}{l}\text { Religion } \\
\text { Buddhist } \\
\text { Islam } \\
\text { Roman Catholic }\end{array}$ & $\begin{array}{l}178(81.7) \\
33(15.1) \\
07(03.2)\end{array}$ \\
\hline $\begin{array}{l}\text { Type of school } \\
\text { Type } 2 \\
\text { Type C } \\
\text { Type } 1 \text { AB }\end{array}$ & $\begin{array}{c}36(16.5) \\
82(37.6) \\
100(45.9) \\
\end{array}$ \\
\hline $\begin{array}{l}\text { Age group (years) } \\
11-12 \\
12-13 \\
13-14\end{array}$ & $\begin{array}{l}104(47.7) \\
75(34.4) \\
39(17.9) \\
\end{array}$ \\
\hline $\begin{array}{l}\text { Family type } \\
\text { Nuclear } \\
\text { Extended }\end{array}$ & $\begin{array}{c}149(68.3) \\
69(31.7)\end{array}$ \\
\hline $\begin{array}{l}\text { Number of children in family } \\
\text { Single child } \\
2-3 \text { children } \\
>3 \text { children }\end{array}$ & $\begin{array}{l}89(40.8) \\
108(49.5) \\
21(09.6)\end{array}$ \\
\hline $\begin{array}{l}\text { Place of residence } \\
\text { Urban } \\
\text { Semi urban }\end{array}$ & $\begin{array}{l}100(45.9) \\
118(54.0) \\
\end{array}$ \\
\hline $\begin{array}{l}\text { Percentage of school attendance } \\
\text { Satisfactory } \\
\text { Not satisfactory }\end{array}$ & $\begin{array}{c}162(74.3) \\
56(25.6)\end{array}$ \\
\hline $\begin{array}{l}\text { Pubertal characteristics } \\
\text { Attained menarche } \\
\text { Not attained menarche }\end{array}$ & $\begin{array}{c}124(56.9) \\
94(43.1)\end{array}$ \\
\hline
\end{tabular}

\section{Psychological stress of adolescents}

The ASQ stress score ranged from 83 to 208, mean stress score being $145.4 \pm 24.3$. Whilst 158 (72.5\%) belonged to the stressed group, 60 (27.5\%) belonged to non-stressed group. Stress was observed for school attendance $(93.1 \%)$, future uncertainty $(92.7 \%)$, school performance $(84.9 \%)$, emerging responsibility $(85.3 \%)$ and conflict of school/leisure time (81.7\%). Most adolescents considered stress of future uncertainty and school attendance the greatest stress inducing factors.

Association of cognitive test scores and ASQ total score

Further analysis was conducted through MANOVA with group (stressed and non-stressed) as independent variables and all ten cognitive test index variables of three cognitive test batteries (WISC-IV, TONI-3 and the two computer based executive function tasks) as dependent variables. MANOVA results indicate a significant effect of stress on entire cognitive function test scores ( $\mathrm{F}$ $(10,206)=4.925, \mathrm{p}<0.001)$.

Association of cognitive test scores and demographic variables

MANCOVA test was used to investigate the main effect of demographic variables on all cognitive test profile using family SES index as covariate. Effects of family type, number of siblings, place of residence, percentage of school attendance and school type on all cognitive test profiles were not statistically significant, $\mathrm{F}(8,208)=0.86, \mathrm{p}>0.05$, $\eta 2=0.03 ; \mathrm{F}(16,414)=1.46, \mathrm{p}>0.05, \eta 2=0.05$ $\mathrm{F}(16,414)=0.538, \mathrm{p}>0.05, \eta 2=0.02 ; \mathrm{F}(16,414)=$ $0.538, p>0.05, \eta 2=0.02$ and $F(14,414)=1.36, p>$ $0.05, \eta 2=0.04$ respectively.

Association of cognitive test scores and socioeconomic variables

SES index was positively correlated with VCI $(\mathrm{r}=0.36 ; \mathrm{p}<0.01)$, WMI $(\mathrm{r}=0.30 ; \mathrm{p}<0.01$, EFSIQ $\mathrm{r}=0.31 ; \mathrm{p}<0.01)$, PRI $(\mathrm{r}=0.27 ; \mathrm{p}<0.01)$, PSI $(\mathrm{r}=0.20$; $\mathrm{p}<0.01)$ and visuo-spatial working memory $(\mathrm{r}=0.17 ; \mathrm{p}<0.05)$. Poor inhibitory control (increased stop signal delay) was associated with low SES index $(\mathrm{r}=-0.22 ; \mathrm{p}<0.01)$. Except for visuo-spatial working memory, an inverse relationship was found between PA index and scores of VCI $(\mathrm{r}=$ $0.34 ; \mathrm{p}<0.01)$, PSI $(\mathrm{r}=-0.25 ; \mathrm{p}<0.01)$, WMI $(\mathrm{r}=-$ $0.24 ; \mathrm{p}<0.01)$, PRI $(\mathrm{r}=-0.26 ; \mathrm{p}<0.01)$, EFSIQ $\mathrm{r}=-$ $0.34 ; \quad \mathrm{p}<0.01), \quad$ TONI $(\mathrm{r}=-0.13 ; \mathrm{p}<0.01) \quad$ and inhibitory control $(\mathrm{r}=0.26 ; \mathrm{p}<0.01)$.

Association of cognitive test scores and nutritional parameters

Table 2 shows the correlation between each cognitive measure and anthropometric indices. HAZ is significantly and positively associated with PSI, WMI, PRI, EFSIQ and visuo-spatial working memory. Decreased HAZ is correlated with poor inhibitory control. WAZ was not correlated with most cognitive indices except visuo-spatial working memory. No significant correlations were observed between BAZ and WHtR with any cognitive test scores. 
Table 2: Correlation between cognitive test scores and anthropometric parameters

\begin{tabular}{|c|c|c|c|c|c|c|c|c|}
\hline Cognitive test & HAZ & WAZ & BAZ & FM\% & WC & HC & WHR & WHtR \\
\hline Wechsler intelligence scale-IV & & & & & & & & \\
\hline Verbal comprehension index (VCI) & $0.07^{\mathrm{ns}}$ & $0.03^{\mathrm{ns}}$ & $-0.05^{\mathrm{ns}}$ & $-0.05^{\mathrm{ns}}$ & $-0.06^{\mathrm{ns}}$ & $-0.07^{\mathrm{ns}}$ & $0.01^{\mathrm{ns}}$ & $-0.03^{\text {ns }}$ \\
\hline Processing speed index (PSI) & $0.28^{* * *}$ & $0.04^{\mathrm{ns}}$ & $-0.10^{\mathrm{ns}}$ & $-0.39^{* * * *}$ & $-0.18^{* *}$ & $-0.15^{*}$ & $-0.23^{*}$ & $-0.18^{\mathrm{ns}}$ \\
\hline Working memory index (WMI) & $0.18^{*}$ & $0.04^{\mathrm{ns}}$ & $-0.12^{\mathrm{ns}}$ & $-0.34^{* * *}$ & $-0.37^{* * *}$ & $-0.30^{* * *}$ & $-0.14^{*}$ & $-0.29^{\mathrm{ns}}$ \\
\hline Perceptual reasoning index (PRI) & $0.14^{*}$ & $0.04^{\mathrm{ns}}$ & $-0.04^{\mathrm{ns}}$ & $-0.03^{\mathrm{ns}}$ & $-0.02^{\mathrm{ns}}$ & $-0.04^{\mathrm{ns}}$ & $0.04^{\mathrm{ns}}$ & $0.14^{\mathrm{ns}}$ \\
\hline $\begin{array}{l}\text { Estimated full scale intelligence } \\
\text { quota (EFSIQ) }\end{array}$ & $0.22^{* *}$ & $0.06^{\mathrm{ns}}$ & $-0.06^{\mathrm{ns}}$ & $-0.12^{\text {ns }}$ & $-0.17^{*}$ & $-0.19^{* *}$ & $-0.06^{\mathrm{ns}}$ & $-0.13^{\text {ns }}$ \\
\hline Test of non-verbal intelligence -3 & $-0.09^{\text {ns }}$ & $0.06^{\mathrm{ns}}$ & $-0.01^{\mathrm{ns}}$ & $-0.20^{* *}$ & $-0.11^{\mathrm{ns}}$ & $-0.12^{\mathrm{ns}}$ & $0.05^{\mathrm{ns}}$ & $-0.02^{\mathrm{ns}}$ \\
\hline Executive function tests & & & & & & & & \\
\hline Visuo-spatial working memory & $0.40^{* * *}$ & $0.31^{* * *}$ & $-0.02^{\mathrm{ns}}$ & $-0.21^{*}$ & $-0.02^{\text {ns }}$ & $0.02^{\mathrm{ns}}$ & $-0.05^{\mathrm{ns}}$ & $-0.16^{\mathrm{ns}}$ \\
\hline Inhibitory control & $-0.22^{* * *}$ & $-0.06^{\mathrm{ns}}$ & $-0.01^{\mathrm{ns}}$ & $0.18^{*}$ & $0.15^{*}$ & $0.14^{*}$ & $0.18^{*}$ & $-0.03^{\mathrm{ns}}$ \\
\hline
\end{tabular}

ns: non-significant, $* \mathrm{p}<0.05, * * \mathrm{p}<0.01, * * * \mathrm{p}<0.001$

Predictors of cognitive performance of female adolescents

School type, family type, place of residence, family size, percentage of school attendance, age group, BAZ and WHtR were not significantly associated with $\mathrm{CP}$ and were excluded from regression model. In bivariate analysis, anthropometric parameters (HAZ, WAZ, FM\%, WC, HC, WHR) and psychosocial variables (SES index, PA index score, ASQ total score) were significantly associated with cognitive function test scores, hence qualifying for multivariable linear regression model. Data showed multi-colinearity (tolerance value $<0.1$ ) between SES index and PA index $(r=0.649 ; p<0.001)$. SES is a significant factor influencing child cognitive development. Accordingly psychosocial adversity index variable was eliminated from prediction variables and SES index included as candidate variable for multiple regression analysis.

Regression analysis was conducted to determine the extent of the variance of cognitive tests as explained by anthropometric and socioeconomic parameters. Results showed that regression model (R2) was statistically significant for the dependent variables; VCI, PRI, WMI, PSI, EFSIQ, TONI score, visuo-spatial working memory and inhibitory control (Table $3 \mathrm{p}<0.05$ ).

Table 3: Predictors of cognitive performance of female adolescents

\begin{tabular}{|c|c|c|c|c|c|c|}
\hline $\begin{array}{c}\text { Cognitive } \\
\text { test }\end{array}$ & Predictor variable & $\begin{array}{c}\text { Standardized Beta } \\
\text { coefficient }\end{array}$ & $p$ & Adjusted $\mathrm{R}^{2}$ & $\mathbf{F}$ & $\begin{array}{l}\text { 95\% confidence } \\
\text { interval }\end{array}$ \\
\hline \multirow[t]{2}{*}{ VCI } & SES index & \multirow{2}{*}{0.362} & $0.001 *$ & \multirow[t]{2}{*}{0.131} & \multirow[t]{2}{*}{32.47} & \multirow{2}{*}{$0.25-0.52$} \\
\hline & Constant & & $0.001 *$ & & & \\
\hline \multirow[t]{5}{*}{ PSI } & SES index & 0.224 & $0.001 *$ & \multirow[t]{5}{*}{0.163} & \multirow[t]{5}{*}{11.51} & $1.78-6.14$ \\
\hline & HAZ & 0.176 & $0.008^{*}$ & & & $0.78-5.14$ \\
\hline & FM\% & -0.263 & $0.001 *$ & & & $-1.74--0.60$ \\
\hline & ASQ total score & -0.203 & $0.002^{*}$ & & & $-0.29--0.71$ \\
\hline & Constant & & $0.001 *$ & & & $80.31-120.62$ \\
\hline \multirow[t]{3}{*}{ WMI } & SES index & 0.267 & $0.001 *$ & \multirow[t]{3}{*}{0.200} & \multirow[t]{3}{*}{28.19} & $0.16-0.43$ \\
\hline & Waist circumference & -0.342 & $0.001 *$ & & & $-0.74--0.35$ \\
\hline & Constant & & $0.001 *$ & & & $101.33-128.68$ \\
\hline \multirow[t]{3}{*}{ PRI } & SES index & 0.263 & $0.001 *$ & \multirow[t]{3}{*}{0.101} & \multirow[t]{3}{*}{7.06} & $1.22-3.51$ \\
\hline & ASQ total score & -0.201 & $0.003^{*}$ & & & $-0.15--0.03$ \\
\hline & Constant & & $0.001 *$ & & & $65.61-89.82$ \\
\hline \multirow[t]{4}{*}{ EFSIQ } & SES index & 0.256 & $0.001 *$ & \multirow[t]{4}{*}{0.109} & \multirow[t]{4}{*}{8.452} & $1.298-3.856$ \\
\hline & HAZ & 0.211 & $0.001 *$ & & & $-1.97--0.49$ \\
\hline & ASQ total score & -0.181 & $0.006^{*}$ & & & $-0.123--0.021$ \\
\hline & Constant & & & & & $64.49-71.64$ \\
\hline \multirow[t]{3}{*}{ TONI } & FM $\%$ & -0.320 & 0.036 & \multirow[t]{3}{*}{0.116} & \multirow[t]{3}{*}{14.72} & $-2.73--0.37$ \\
\hline & ASQ total score & -0.159 & $0.001 *$ & & & $-2.82--0.72$ \\
\hline & Constant & & $0.001 *$ & & & $45.36-130.07$ \\
\hline \multirow{4}{*}{$\begin{array}{l}\text { Visuo-spatial working } \\
\text { memory }\end{array}$} & HAZ & 0.412 & $0.001 *$ & \multirow[t]{4}{*}{0.185} & \multirow[t]{4}{*}{17.401} & $-2.224--1.109$ \\
\hline & SES index & 0.164 & $0.008^{*}$ & & & $0.025-0.165$ \\
\hline & FM\% & -0.164 & $0.010^{*}$ & & & $0.104-0.750$ \\
\hline & Constant & & $0.001 *$ & & & $18.68-20.75$ \\
\hline \multirow[t]{3}{*}{ Inhibitory control } & SES index & 0.216 & $0.001 *$ & \multirow[t]{3}{*}{0.089} & \multirow[t]{3}{*}{11.54} & $-2.82--0.72$ \\
\hline & HAZ & 0.226 & $0.001 *$ & & & $-20.82--5.76$ \\
\hline & Constant & & $0.001 *$ & & & $256.95-329.88$ \\
\hline
\end{tabular}

A combination of SES index, ASQ total score and HAZ significantly accounted for $10.9 \%$ variance of EFSIQ $(p=0.001)$. SES index was found to be positively and significantly associated with most cognitive variables including VCI, PSI, WMI, PRI, EFSIQ, visuo spatial working memory and inhibitory control (Table 3). Increased HAZ was found positively associated with PSI, EFSIQ, visuo spatial working memory and inhibitory control scores in the multivariable model. A single unit increase of $\mathrm{FM} \%$ resulted in 0.263 unit reduction of $(\beta=-0.263,95 \% \mathrm{CI} ;-1.74--0.60)$ PSI score, 0.320 unit reduction in TONI score $(\beta=-0.320,95 \% \mathrm{CI}$; $2.73--0.37)$ and 0.164 unit reduction of visuo spatial working memory $(\beta=-0.164,95 \% \quad C I$; $0.104-0.750)$. In the stepwise regression WAZ was 
eliminated from the model due to its insignificant association after bonferroni correction.

\section{Discussion}

The present study shows that anthropometric nutritional indicators (HAZ, FM\% and WC), stress, SES index and ASQ total score were significant predictors of CP amongst early female adolescents. Strengths of the present cross sectional study were the comprehensive analysis of $\mathrm{CP}$ using different cognitive test batteries which provide reliable findings regarding factors influencing CP. Chosen cognitive abilities are vulnerable for macronutrient deficiencies shown in previous studies ${ }^{7,19}$. In line with the findings of the present study, stunting (low HAZ) is negatively associated with cognitive outcomes. Decreased availability of energy and micronutrients during the adolescent growth period resulted in decreased linear growth, reduced neurodevelopment of brain and changes in behaviour and cognition ${ }^{6,20}$. Moreover, long term protein energy malnutrition leads to altered brain architecture and neuronal functions ${ }^{21}$. Retardation of growth is observed in the hippocampus, frontal lobe and temporal lobes which are involved in higher order cognitive tasks ${ }^{22}$. Another aspect of the role of undernutrition on deficit cognitive outcomes is explained using a social isolation theory by Grantham and Henningham ${ }^{23}$. This theory describes that undernourished children are less explorative and apathetic with reduced activity which contribute to poor environmental stimulation which in turn leads to poor cognitive development. Impaired cognitive function in adolescence is more likely to continue into adult life and may hinder development of the full intelligence potential as an adult ${ }^{24}$.

Our study found that family SES index is a robust indicator of most cognitive indices of female adolescents. This supports previous studies showing strong positive association of higher parental SES with higher scores on cognitive measures and academic tests from early childhood through adolescence ${ }^{12,24}$. Evidence suggests that SES related difference in neural development begins in utero ${ }^{9}$. SES index significantly predicts verbal comprehension and executive functions (inhibitory control and visuo-spatial working memory) in this study. In a recent review, the role of underlying SES associated differences in neurocognitive abilities is attributed to multiple factors including prenatal influences, postnatal care and cognitive stimulation ${ }^{9}$. Inappropriate parenting practices are correlated with emotional and behavioral problems in children that even contribute to problems in later years of 1 life $\mathrm{e}^{25}$.

Compared to adolescents from higher SES backgrounds, adolescents from low SES backgrounds show more psychopathologies like internalizing (depression, schizophrenia) and externalizing behaviours ${ }^{26}$. Persistent stress activates the hypothalamic-pituitary-adrenal axis and elevates stress hormones which adversely affect brain neurodevelopment and compromise cognitive and academic achievements ${ }^{27}$. Continued maturation of cortico-limbic regions in adolescence makes the adolescent brain more vulnerable to stress $^{28}$. Some studies suggest that stress exerted structural changes in the prefrontal cortex during adolescence would cause long lasting psychopathologies compared to stress experienced during adult life ${ }^{29}$. There is evidence that school based working memory training boosts the performance on mathematics, IQ and class room performance of children and adolescents $\mathrm{s}^{30}$. Our findings revealed that SES plays a crucial role in the neurocognitive profile of female adolescents. The study highlights the influence of low HAZ, SES, psychological stress and increased fatness indicators contribute to poor $\mathrm{CP}$ of female adolescents. Future research is needed to elucidate the role of fatness parameters on $\mathrm{CP}$.

\section{Conclusions}

Poor socioeconomic state, stress, stunting and fatness were negatively linked with $\mathrm{CP}$ of female adolescents. School type, family type, place of residence, family size, percentage of school attendance, age group, BAZ and WHtR were not significantly associated with CP.

\section{References}

1. World Health Organization, (2005), 'Nutrition in adolescence: issues and challenges for the health sector: issues in adolescent health and development', Geneva. Available at:

http://www.who.int/iris/handle/10665/433 42 [Accessed on 16 June 2017.

2. Sowell E. Mapping continued brain growth and gray matter density reduction in dorsal frontal cortex: inverse relationships during post- adolescent brain maturation. Journal of Neuroscience 2001; 21: 8819-9929. https://doi.org/10.1523/JNEUROSCI.2122-08819.2001

PMid: 11698594 PMCid: PMC6762261

3. Crookston B, Penny M, Alder S, Dickerson T, Merrill R, Stanford J, et al. Children who recover from early stunting and children who are not stunted demonstrate similar levels of cognition. Journal of Nutrition 2010; 140(11): 19962001. 
https://doi.org/10.3945/jn.109.118927

PMid: 20844188

4. Bornstein M, Putnick D. Cognitive and socioemotional caregiving in developing countries. Child Development 2012; 83: 46-61.

https://doi.org/10.1111/j.14678624.2011.0

1673.x

PMid: 22277006 PMCid: PMC3270892

5. Fink G, Rockers PC. Childhood growth, schooling, and cognitive development: further evidence from the Young Lives study. American Journal of Clinical Nutrition 2014; 100(1): 182-8.

https://doi.org/10.3945/ajen.113.080960

PMid: 24808488

6. Sokolovic N, Selvam S, Srinivasan K, Thankachan P, Kurpad A, Thomas T. Catch-up growth does not associate with cognitive development in Indian schoolage children. European Journal of Clinical Nutrition 2014; 68(1): 14-8. https://doi.org/10.1038/ejen.2013.208 PMid: 24169458

7. Poh B, Rojroonwasinkul N, Le Nyugen B, Budiman B, Ng L, Soonthorndhada K, et al. Relationship between anthropometric indicators and cognitive performance in Southeast Asian school-aged children. British Journal of Nutrition 2013; 110(S3): S57-S64. https://doi.org/10.1017/S00071145130020 79

PMid: 24016767

8. Noble $\mathrm{K}$, Norman $\mathrm{M}$, Farah $\mathrm{M}$. Neurocognitive correlates of socioeconomic status in kindergarten children. Developmental Science 2005; 8(1): 74-87.

https://doi.org/10.1111/j.14677687.2005.0 0394.x

PMid: 15647068

9. Hackman DA, Farah MJ, Meaney MJ. Socioeconomic status and the brain: mechanistic insights from human and animal research. Nature Reviews Neuroscience 2010; 11(9): 651. https://doi.org/10.1038/nrn2897 PMid: 20725096 PMCid: PMC2950073

10. Wickramasinghe V, Lamabadusuriya $\mathrm{S}$, Cleghorn G, Davies P. Assessment of body composition in Sri Lankan children: Validation of a skin fold thickness equation. Ceylon Medical Journal 2008; 53(3). 83-8.

https://doi.org/10.4038/cmj.v53i3.247

PMid: 18982800

11. Ashwell M, Hsieh SD. Six reasons why the waist-to-height ratio is a rapid and effective global indicator for health risks of obesity and how its use could simplify the international public health message on obesity. International Journal of Food Sciences and Nutrition 2005; 56(5): 303-7. https://doi.org/10.1080/096374805001950 66

PMid: 16236591

12. McLoyd V. Socioeconomic disadvantage and child development. American Psychologist 1998; 53(2): 185. https://doi.org/10.1037/0003066X.53.2.18 5

PMid: 9491747

13. Hollingshead A. Four factor index of social status. Yale Journal of Sociology 2011; 8: 21-52.

14. Bradley R, Corwyn R. Socioeconomic status and child development. Annual Review of Psychology 2002; 53(1): 37199.

https://doi.org/10.1146/annurev.psych.53.

100901.135233

PMid: 11752490

15. Byrne DG, Mazanov J. Adolescent stress and future smoking behaviour: A prospective investigation. Journal of Psychosomatic Research 2003; 54(4): 313-21.

https://doi.org/10.1016/S00223999(02)00 411-7

16. Kathriarachchi LS, Hewage DC, Wimalasekera SW, Ranjan R, Mendis ALS. Home school environmental factors and peer pressure contributing to stress among adolescents in Colombo district in Sri Lanka - Preliminary results. Proceedings of South Asian Association of Physiologist Conference 2016. pp.229.

17. Wimalasekara S. 2010. The effects of iron deficiency on cognitive function and neurophysiological function in early adolescent females. $\mathrm{PhD}$ Thesis. University of Sri Jayewardenepura. 
18. Brown L, Sherbenou J, Johnsen S. (1990). Test of non-verbal intelligence (2nd edition). Austin, TX, USA, Pro-Ed.

19. Eilander A, Muthayya S, van der Knaap H, Srinivasan K, Thomas T, Kok F, et al. Undernutrition, fatty acid and micronutrient status in relation to cognitive performance in Indian school children: a cross-sectional study. British Journal of Nutrition 2010; 103(7): 105664.

https://doi.org/10.1017/S00071145099927 3X

PMid: 20003612

20. Kar B, Rao S, Chandramouli B. Cognitive development in children with chronic protein energy malnutrition. Behavioral and Brain Functions 2008; 4(1): 31.

https://doi.org/10.1186/1744-9081-4-31

PMid: 18652660 PMCid: PMC2519065

21. Bryan J, Osendarp S, Hughes D, Calvaresi E, Baghurst K, van Klinken J. Nutrients for cognitive development in school-aged children. Nutrition Reviews 2004; 62(8): 295-306.

https://doi.org/10.1111/j.17534887.2004.t b00055.x

PMid: 15478684

22. Benton D, Winichagoon $\mathrm{P}, \mathrm{Ng} \mathrm{T}$, Tee E, Isabelle $\mathrm{M}$. Symposium on nutrition and cognition: towards research and application for different life stages. Asia Pacific Journal of Clinical Nutrition 2012; 12: 104-24.

23. Grantham-McGregor S, BakerHenningham H. Review of the evidence linking protein and energy to mental development. Public Health Nutrition 2005; 8(7a): 1191-201.

https://doi.org/10.1079/PHN2005805

PMid: 16277829

24. Hanscombe K, Trzaskowski M, Haworth C, Davis O, Dale P, Plomin R. Socioeconomic status and children's intelligence: In a UK-representative sample SES moderates the environmental, not genetic, effect on IQ. PloS One 2012; 7(2): e30320.

https://doi.org/10.1371/journal.pone.0030 320

PMid: 22312423 PMCid: PMC3270016

25. sWadsworth M, Raviv T, Compas B, Connor-Smith J. Parent and adolescent responses to poverty related stress: Tests of mediated and moderated coping models. Journal of Child and Family Studies 2005; 14(2): 283-98. https://doi.org/10.1007/s10826-005-50562

26. Qin S, Hermans E, van Marle H, Luo J. Fernández G. Acute psychological stress reduces working memory-related activity in the dorsolateral prefrontal cortex. Biological Psychiatry 2009; 66(1), 25-32. https://doi.org/10.1016/j.biopsych.2009.03 .006

PMid: 19403118

27. Arnsten A, Li B. Neurobiology of executive functions: catecholamine influences on prefrontal cortical functions. Biological Psychiatry 2005; 57(11): $1377-$ 84.

https://doi.org/10.1016/j.biopsych.2004.08 .019

PMid: 15950011

28. Romeo R. The impact of stress on the structure of the adolescent brain: implications for adolescent mental health. Brain Research 2017; 1654: 185-91. https://doi.org/10.1016/j.brainres.2016.03. 021

PMid: 27021951

29. Walker S, Wachs T, Gardner J, Lozoff B, Wasserman G, Pollitt E, et al. Child development: risk factors for adverse outcomes in developing countries. Lancet 2007; 369(9556): 145-57. https://doi.org/10.1016/S01406736(07)60 076-2

30. St Clair-Thompson H, Stevens R, Hunt A, Bolder E. Educational Psychology: An International Journal of Experimental Educational Psychology. Educational Psychology 2010; 30(2): 203-19. https://doi.org/10.1080/014434109035092 59 